\title{
Applicability of Microfinance for Adaptation to Sea Level Rise Impacts
}

\author{
Amornpun Kulpraneet ${ }^{1}$ \\ ${ }^{1}$ Mahidol University, Thailand \\ Correspondence: Amornpun Kulpraneet, Ph.D. Environment and Resource Studies, Mahidol University, \\ Thailand. E-mail: AmornpunK@Gmail.com
}

Received: August 18, 2017

Accepted: September 27, 2017

Online Published: September 29, 2017

doi:10.5539/ep.v6n2p48

URL: https://doi.org/10.5539/ep.v6n2p48

\begin{abstract}
The aim of this study is to study the applicability of hypothetical microfinance for household adaptation to sea level rise impacts at community level. The study examines two hypothesis: 1) microfinance can (cannot) be applied as an adaptive measure to the impacts of sea level rise; 2) whether or not the factors of risk perceptions, attitudes, social references, microfinance conditions, government supports, and demographic influence an individual participation to a designed microfinance. The study sites are six vulnerable coastal villages located in the Gulf of Thailand. A designed microfinance for adaptation to sea level rise impacts is assumed in hypothetical market and tested with residents in the villages. Acceptance analysis, Pearson correlation, and stepwise regression analysis are used to test the hypothesis of the study.

The study results reveal that microfinance can be applied for household adaptation to sea level rise impacts at community level. However, there are some correlated factors that affect individual participation to the designed microfinance. The likelihood of successful implementation of microfinance for the adaptation purposes is depended on how those factors affecting participation are properly addressed by implementer.
\end{abstract}

Keywords: acceptance, adaptation, intention to participate, microfinance, sea level rise impacts

\section{Introduction}

Climate change from the effect of greenhouse gases impacts people around the globe. Various mitigation plans to reduce sources of greenhouse gases have been induced widely with certain degree of success. In parallel, adaptation approaches that allow vulnerable parties better adjust with the climate change are also encouraged. Those adaptations can be categorized into social groups as collective (international), national, and community (Chinvanno, 2007). Among those, the adaptation at community level particularly serves well to real vulnerable party's requirements. However, it is considered far from adequate (Pettengell, 2010). The climate change impacts to coastal areas have various aspects. Examples of them include increasing of sea level, sea water temperature, precipitation intensity, wave height, storm frequency, water run-off, and atmospheric $\mathrm{CO}_{2}$ Considering all, the sea level rise is one the most serious impacts. Its impacts can be varied from place to place, and require differentiated degree of adaptations. The adaptation to sea level rise impacts that suits to local and be practical thus is the necessity.

The aim of this study is to study the possible use of microfinance for adaptation to sea level rise impacts at community level. Microfinance is a financial self-help among members in a social group (Jindal \& Rajulu, 2010). In a community, it may be a good financial tool that supports members who need to invest for their household's physical adaptive measures. The study examined two hypotheses, which were: 1) microfinance can (cannot) be applied as a financial adaptive measure for the impacts of sea level rise; 2) whether or not the factors of risk perceptions, attitudes, social references, microfinance conditions, government supports, and demographic influence an individual household's degree of participation to the microfinance. The study selected six coastal villages as the studied sites. Those studied villages locate along the coast of the Upper Gulf of Thailand, the most impacted area by sea level rise in Thailand and one of the most impacted in Southeast Asia (Umitsu, 2000). The villages include: a) Sahakon village and Sandap village in Tambon Phan Thai Norasing (Tambon is a territory governed as an administrative or political unit of a province in Thailand); b) Khun Samut Chin village and Khlong Suan village in Tambon Laem Fapha; and c) Si Long village and Khlong Nang Hong village in Tambon Khlong Dan. 
The study designed structures and conditions of a microfinance particular for household's adaptation to sea level rise impacts by using focus group interview with microfinance's stakeholders. Such designed microfinance (hereinafter refers to 'microfinance for sea level rise impacts') was a hypothetical and presented to four hundred households/ respondents (the required sample size) of the six studied villages. Respondents then were personally interviewed, following another predefined questionnaire, for their intention to participate to the microfinance for sea level rise impacts. The personal interview using questionnaire is the method typically used for collecting data at the household level in developing countries (United Nation[UN], 2005). In addition, respondents were asked about their opinion (agreement/ disagreement) related with risk perceptions to sea level rise impacts, attitudes toward general microfinance scheme, and other factors that might affect their participation to microfinance. Likert scaling was used to rate respondent's agreement/ disagreement on those additional asked subjects.

The analysis of the study was divided into two parts, which included the acceptance and intention to participate to the microfinance for sea level rise impacts. The acceptance to microfinance for sea level rise impacts was analyzed by the ratio of acceptance considering sole factor of respondent's attitudes toward microfinance. To obtain the ratio, summation of value that respondents assigned was divided by summation of maximum possible values (in likert scaling) to attitude items. The ratio of acceptance indicates whether microfinance is acceptable by respondents and can be applied for adaptation to sea level rise impacts. For the intention to participate to microfinance for sea level rise impacts, the study measured percentage of respondent's confirmation of their participation to the microfinance. In addition, a model for prediction of intention to participate with microfinance for sea level rise impacts was developed using Pearson correlation and stepwise regression analysis. Such analyses were used to find significant relationships between a dependent variable (respondent's degree of intention to participation) and independent variables (factors affecting microfinance participation and demographic factors).

Results of study are presented herein this paper. They are references for those who may want to apply and implement microfinance successfully for adaptations to climate change impacts. It is particular worthwhile for vulnerable coastal parties who can adopt directly the study results to buildup financial self-cooperation in their community in mitigating and adapting to the impacts of sea level rise.

\section{Review of Sea Level Rise Impacts, Adaptation, and Microfinance}

Sea level rise is one of the most serious threats of climate change that is currently impacting coastal areas. This is due to the continued increase of sea level from polar glacier melting and sea thermal expansion. Potential impacts cover both socio-economic and biogeophysical sectors as the results of increasing flood frequency, inundation, coastal erosion, rising of water table, and saltwater intrusion (Nicholls, 2003; Klein \& Nicholls, 1999). The damages from those impacts can be categorized into direct and indirect (Messner \& Meyer, 2005). The actual degree of damages from sea level rise to a specific coast depends on the adaptability of the affected socio-economic and ecological systems of that coast, as well as its potential for harm by a hazardous event (Cutter, 1996). Scientific knowledge about the increase in sea level is considerable. A number of studies (Meehl et al., 2007; Wigley \& Raper 1992; Smith \& Tirpak, 1990; and Hoffman et al., 1983) were conducted with different results. However, the variations in sea level are normally measured in two ways. Eustatic sea level represents the level of the ocean independent of land movements. Relative sea level is measured relative to the local land surface. Most researchers focus on relative sea level change (Carter \& La Rovere, 2001).

In response to sea level rise, there are three possible coastal adaptation strategies (Nicholls, 2007): a) Retreat abandonment the current areas and resettlement in new development areas; b) Accommodate - continue occupancy the current areas but induce adaptive management responses; and c) Protect - defense the areas by using both structural (hard) and non-structural (soft). In fact, adaptation can come in a huge variety of forms. Smit and Pilifosova (2001) referred adaptation broadly as the adjustments in ecological, social, or economic systems in response to actual or expected climatic stimuli and their effects or impacts. Thorne, Kantor, and Hossain (2007) gave the definition that adaptation referred to the use of any number of strategies, practices, processes, and technologies that support people in dealing with the impacts of climate change. Adaptation measures could range from actions being taken by individuals or by communities all the way through to government policies. Differentiation in the adaptations to climate change also include: (i) adaptation that economic agents will undertake on their own in the absence of government policies or programs, and (ii) actions that a government undertakes (Sathaye \& Christensen, 1998). In another view, adaptations are classified into two main categories, autonomous and planned (Schneider \& Sarukhan, 2001). Autonomous adaptations take place in reactive response to climatic stimuli without directed intervention by a public agency. Planned adaptations can be reactive or anticipatory, but must be undertaken before impacts are apparent. In a perfect world of no market failures, autonomous adaptation is the best way to adapt to climate change and public involvement will be 
unnecessary (Malik et al., 2010). However, due to constraints with respect to information and resources, autonomous adaptation alone may not be optimal. In other words, there is no single set of adaptation can be universally appropriate. Therefore, the success of adaptations is depended on the flexibility and effectiveness of the measures, such as their ability to meet objectives and local needs given a range of future climate scenarios (Smith \& Lenhart, 1996, cited in Smit \& Pilifosova, 2001; Carter, 1996).

Microfinance can be used for a variety of purposes. Examples of those include: 'microfinance for agriculture farming' (Andrews, 2006) and 'microfinance for water and sanitation' that lending to people required drinkable water accessibility and storage (Kouassi-Komlan, Faso, Fonseca, 2004). According to Hammill, Matthew, and McCarter (2008), microfinance can be used as adaptation measure to climate change impacts as well. They define that microfinance is the delivery of loans (credit), savings, insurance and other financial services to the group of people so they can engage in productive activities, helping them build assets, stabilize consumption and protect themselves against risks or impacts. Microfinance therefore can make many contributions to livelihood asset such as increasing household financial saving, strengthening social network, and capital for natural resources management. Microfinance works best to support poor people, or those who stay just above the poverty line (Matthew \& McCarter, 2008; Cohen, 2003 cited in Hammill, 2008). Target groups of microfinance may not be homogeneous. Therefore, no single microfinance can possibly match needs of groups that its programs intended to serve. In addition, the participation of people to microfinance is depended on, but not limited to, their demographic factor and social capital (Togba, 2009), including microfinance's terms and conditions (Atieno, 2001). Different forms of microfinance and their related administrative are necessary to cater and to satisfy the varying needs of the groups (Haim, Abidin, Zamzuri Noor \& Majid, 2007).

\section{Conceptual Framework of Study}

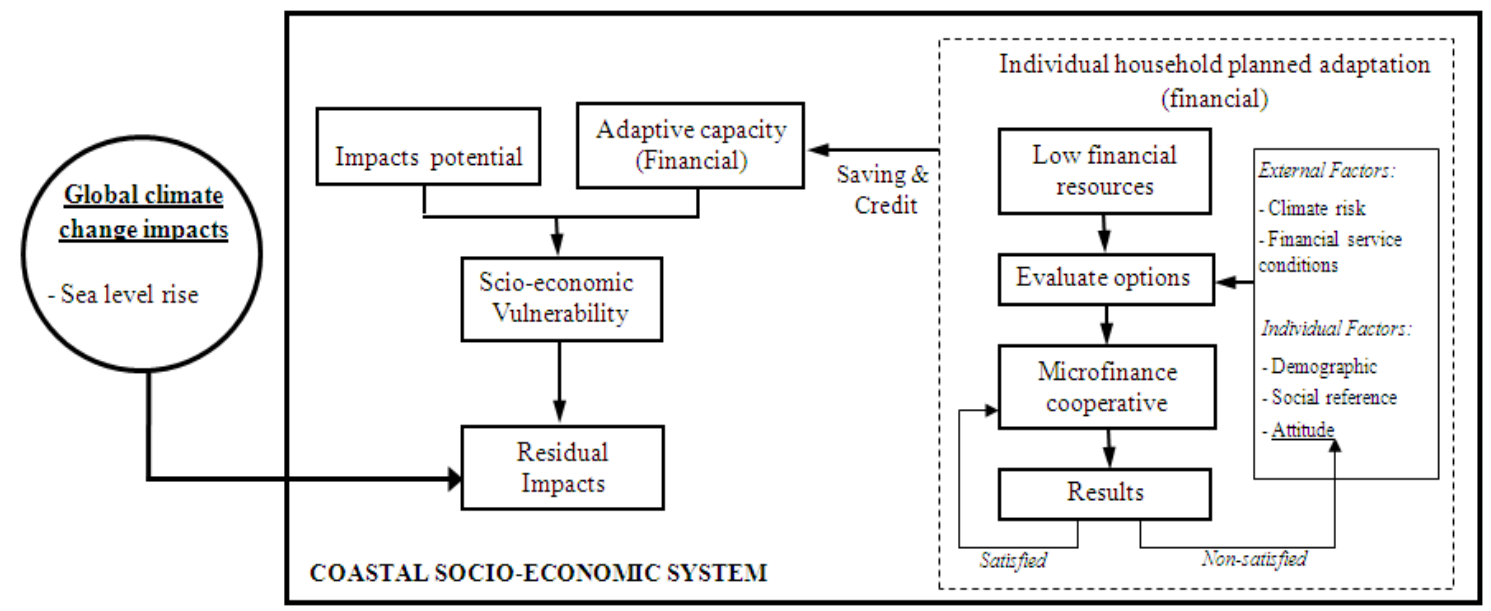

Figure 1. Conceptual framework of sea level rise impacts, adaptation (using microfinance), and vulnerability of a coastal socio-economic system

The conceptual framework is developed by adjusting vulnerability models of Klein and Nicholls (1999), including Mimura and Harasawa (2000, cited in Mclean \& Tsyban, 2001), and then combining with consumer's behavior model of Engel et al. (1986, cited in Kotler, 1991). The framework demonstrates the linkages between the impacts of sea level rise, the adaptive capacity via the usage of microfinance, and the vulnerability of a coastal socio-economic system. Vulnerability is the net of impacts minus adaptive capacity (Smit \& Pilifosova, 2001). As such, given the impacts are constant, the more a community can adapt to the impacts is the less community will be vulnerable. Individual household, in a vulnerable coastal community that has low financial adaptive capacity, seeks the most appropriate financial service option to increase its financial capabilities. In evaluating options, factors of attitudes, social references, demographic, including other external factors (e.g. the level of climate risks and the conditions of financial service options) influence individual household's evaluation processes. Microfinance is one of options that responds to household's financial requirements and also creates cooperative among members/ households in a community. Microfinance is considered as a planned adaptation due to its scheme is for financial planning for future. Microfinance should be designed and implemented considering localization (fits for community requirements), creation of fairness, and being self-continuity (Churchill, Hirschland, \& Painter, 2002). Successful microfinance creates repeating or continuing participations 
of members, which can enhance financial adaptive capacity of community through the mechanisms of saving and credit. On the contrary, unsuccessful one may cause individual's negative attitude toward microfinance and results to lower financial cooperative and adaptive capacity in community.

\section{Study Area and Study Sites}

The study area is the coastal area in the upper Gulf of Thailand. The Gulf of Thailand covers roughly 320000 $\mathrm{km}^{2}$ and is relatively shallow (mean depth is $45 \mathrm{~m}$, and the maximum depth is $80 \mathrm{~m}$ ). This makes for a slow water exchange, and the strong water outflow from the rivers makes the Gulf low in salinity and rich in sediments (Burnetta et al., 2007). The decrease in sediment yield, natural land subsidence, sea level rise, and the impacts from waves and storms, all combined to cause the coastal problems in the Gulf of Thailand. Following an estimation, the sea level in the Upper Gulf of Thailand will rise 10-100 cm in the year 2050. An annual relative sea level rise of $1 \mathrm{~cm}$ in some areas of the Gulf of Thailand will result in an apparent coastal retreat of 5 meters per year (Winterwerp et al., 2005; Ittaro, 2001, cited in Jarungrattanapong \& Manasboonphempool 2007).

Three vulnerable coastal Tambons (a Tambon is a territory governed as an administrative or political unit of a province in Thailand) were selected for this study by considering: a) coastal characteristics throughout Thailand (mudflat, sand, and rock; the mudflat coast in the Gulf of Thailand was selected because it was the most vulnerable); b) high risk areas in the Gulf of Thailand identified by sea level rise model; and c) expert recommendations. Figure 2 and Table 1 below respectively show the location and general information of those selected Tambons.

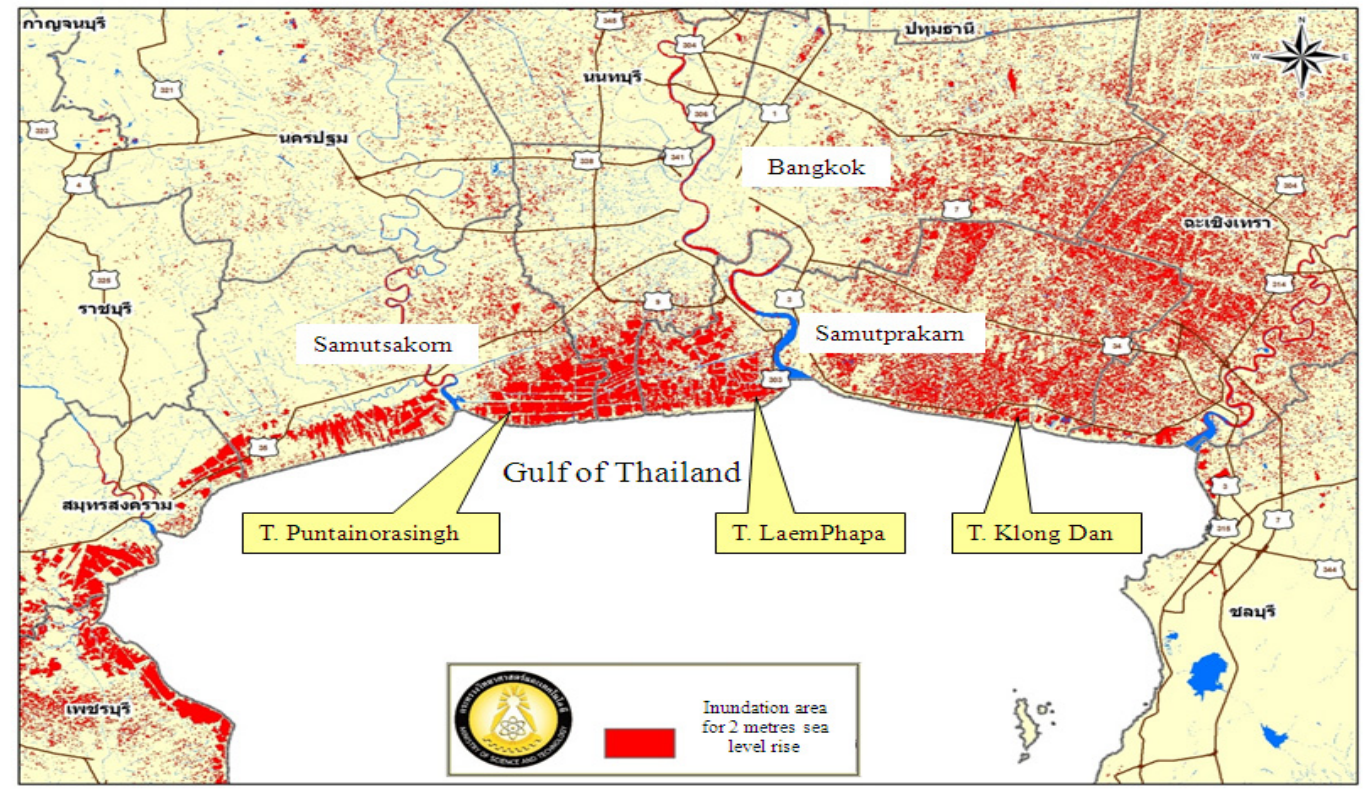

Figure 2. Inundation coastal areas in the Gulf of Thailand for the scenario of 2 meter sea level rise and the studied Tambons

Source: Climate Change Information Center, Department of Science and Technology (2009) Inundation areas of the Gulf of Thailand for scenario 2 meter sea level rise. Chulalongkorn University, Bangkok 
Table 1. Studied Tambon Klongdan, Tambon Laemphapa, and Tambon Pantainorasingh and their number of villages, male and female, number of households, and household per capita income

\begin{tabular}{|c|c|c|c|c|c|}
\hline \multirow{2}{*}{ Provinces } & \multirow{2}{*}{ Tambons } & \multicolumn{3}{|c|}{ Population Statistics (2) } & \multirow{2}{*}{$\begin{array}{l}\text {-Per capita income Baht (3) } \\
\text { s }\end{array}$} \\
\hline & & No. villages (1) & \multicolumn{2}{|c|}{ MaleFemaleNo. Household } & \\
\hline Samutsakorn & Pantainorasingh & 8 & 85919714 & 10772 & 53756 \\
\hline Samutprakarn & Laemphapa & 8 & 32492683 & 1658 & 49847 \\
\hline \multirow[t]{2}{*}{ Samutprakarn } & Klongdan & 10 & 87418920 & 4478 & 53669 \\
\hline & \multicolumn{2}{|c|}{ Total number of households } & & 16908 & \\
\hline
\end{tabular}

Source:

1) Provincial Cooperative staffs (personal communication, 2010)

2) Department of Provincial Administration (2010). Population statistics as of December 2010, Thailand. http://ww.DOPA.go.th, cited March 5, 2011.

3) Community Development Department (2009). Introduction to household information, Ministry of Interior, Thailand

Thereafter, two most impacted villages (by sea level rise) of each studied Tambon were selected according to the recommendation of the Administrative Organization (a local authority). Of the three studied Tambons, the total number of selected villages was six. Those villages became the final study sites. They are presented as follow:

Table 2. Six studied villages

\begin{tabular}{lll}
\hline \multicolumn{1}{c}{ Tambons } & & \multicolumn{1}{c}{ Study sites (Villages) } \\
\hline \multirow{2}{*}{ Pantainorasingh } & - & Sahakorn \\
& - & Sandab \\
Laemphapa & - & Kunsamutrchin \\
& - & Klongsuan \\
Klongdan & - & Srilong \\
& - & Klong-Nang-Hong (K-N-H) \\
\hline
\end{tabular}

\section{Material and Methods}

\subsection{Limitations and Assumptions of Study}

- The application of microfinance for household's adaptation to sea level rise impacts is an original idea, and has never been actually implemented. Accordingly, in this study, the use of designed microfinance for sea level rise impacts is assumed in a hypothetical market. All responds of respondents are their stated intention and preference.

- The study focuses the applicability of microfinance designed for adaptation to sea level rise impacts. The effectiveness of such microfinance in view of self-sufficient of fund (amounts obtained from household's saving to microfinance) to household adaptation cost requirements is not analyzed. This is due to the household adaptation costs to sea level rise impacts need different study and particular assessment. Without the references of adaptation cost requirements, the effectiveness of microfinance then cannot be examined.

\subsection{Sample Size and Sampling Method}

Following the formula of Yamane (1973): $\mathrm{n}=\mathrm{N} /\left(1+\mathrm{Ne}^{2}\right)$, whereby $\mathrm{n}=$ sample size required, $\mathrm{N}=$ population size, and e = allowable margin of error; and given the allowable margin of error at 0.05 , the minimum sample size required for this study is 391 households to represent the total number of households at 16908 of the studied Tambons. The study used a sample size of 400 allocated equally to every selected village (65-67 households per village for six villages). 
Most residents in the studied villages have lived in areas with same environments, and they generally have same occupation. For selecting the household sampling unit, the study then used a simple random sampling method (randomly selected the assigned running number households) since the target population was in the homogenous group. Inclusion criterion included participants who were household leaders or household members who mainly had generated income for their households for at least last six months. Exclusion criteria excluded participants who were unable to provide good information such as persons over 80 years of age, or who had not been living continuously in the surveyed house over the last 12 months.

\subsection{Design of Microfinance for Sea Level Rise Impacts}

Focus group interviews were conducted among key stakeholders of studied villages and relevant local authorities to design an ideal microfinance for adaptation to sea level rise impacts. Such microfinance was designed with specific aims to encourage adaptation processes in a community and to support individual household's adaptation practices. During the focus group, the required conditions of the microfinance were discussed. Those conditions included objective of microfinance, source of fund, loan policy, membership benefits, management, accounting and audit. The designed microfinance then was assumed in a hypothetical market and presented to respondents to test their acceptance and to assess their intention to participate.

\subsection{Identification of Factors Affecting Microfinance Participation}

The factors affecting acceptance and participation of a person to a subject usually are relevant to personal behavior, beliefs, attitudes and values: BBAV (Niemirowski, Baldwin \& Wearing, 2003). In this study, eleven items that might influence a studied household in participating with microfinance for sea level rise impacts were identified through a questionnaire pre-testing with one studied village. Those identified items were grouped into factors of: 1) risk perception to sea level rise impacts; 2) attitudes toward microfinance; 3) social influences; 4) conditions of microfinance; and 5) government supports. Such factors were hypothesized their influencing to the household's degree of acceptance and intention to the microfinance. Likert scale was used in a formulated questionnaire, in which respondents were asked to mark their agreement with identified items on the continuum having two extreme ends. The continuum was divided into seven intervals of measurement (numbers $0-6$ ) starting with "fully disagree" to "fully agree". Results of identified items and their measurement are shown in Figure 3.

\subsection{Test of Applicability of Microfinance for Sea Level Rise Impacts}

The applicability of microfinance whether it can be applied as an adaptive measure to sea level rise impacts was examined by analyzing the acceptance of respondents toward the designed microfinance. The microfinance is applicable for adaptation purposes if most respondents accept its benefits. Accordingly, the attitudes of respondents toward the microfinance for sea level rise impacts were measured in order to indicate the acceptance of respondents. The study adopted methodology of Sahu and Gupta (2007) for obtaining acceptance ratio. The ratio was calculated by average value respondents assigned to attitude items divided by the maximum value possible for such items. A criterion for applicability of microfinance for sea level rise impacts was that acceptance values of all attitude items were above average (or 0.5). The equation for calculating of the "Ratio of Acceptance" is shown in equation 1 and analysis results are shown in Table 4.

$$
\begin{aligned}
& \quad \text { Ratio of Acceptance }(V)=\frac{\sum_{i=1}^{N}\left(\sum_{j=1}^{S_{v}} R_{j}^{i}\right)}{N^{*} M^{*} S_{V}} \\
& \mathrm{~V}=\text { Variable } \\
& \mathrm{S}_{\mathrm{V}}=\text { Number of Sub-variables of Variable } \mathrm{V} \\
& \mathrm{M}=\text { Maximum Rating } \\
& \mathrm{R}_{\mathrm{j}}^{\mathrm{i}}=\text { Actual Rating for the } \mathrm{j}^{\text {th }} \text { Sub-variable of the } \mathrm{i}^{\text {th }} \text { Response } \\
& \mathrm{N}=\text { Maximum Number of Responses }
\end{aligned}
$$

\subsection{Analysis of Factors Affecting Microfinance Participation and Development of Intention to Participate Model}

The study used Pearson correlation analysis to examine the correlation of the hypothesized factors affecting participation and respondent's intention to participate with microfinance for sea level rise impacts. In addition, stepwise regression was used to develop a model of predicting intention to participate. The study applied the adjusted R square to test the fitness of such developed model. The Pearson correlation and stepwise regression analysis are used widely to examine: a) the relationship between variables and; b) determine the principle 
independent variables that can best explain the model/ dependent variable (Hocking, 1976).

\section{The Study Results}

\begin{tabular}{|c|c|c|c|c|c|c|c|c|}
\hline \multirow{3}{*}{\multicolumn{3}{|c|}{ Hypothesized factors ${ }^{(1)}$}} & \multicolumn{6}{|c|}{ Average score } \\
\hline & & & \multicolumn{4}{|c|}{ Fully disagree } & \multicolumn{2}{|c|}{ Fully agree } \\
\hline & & & $\begin{array}{ll}0 & 1 \\
\end{array}$ & 2 & 3 & 4 & 5 & 6 \\
\hline \multirow{3}{*}{ 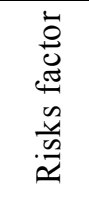 } & \multirow{3}{*}{$\begin{array}{l}\text { R1: 'Perceive of risks' from the impacts } \\
\text { of sea level rise are the protective } \\
\text { motivation }\end{array}$} & R1.1 & & & & & & \\
\hline & & $\mathrm{R} 1.2$ & & & & & & \\
\hline & & R1.3 & & & & & & \\
\hline \multirow{8}{*}{ 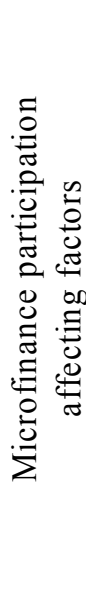 } & \multirow{3}{*}{$\begin{array}{l}\text { A1: 'Attitudes' toward microfinance are } \\
\text { predictor of intention to participate }\end{array}$} & A 1.1 & & & & & & \\
\hline & & A 1.2 & & & & & & \\
\hline & & A 1.3 & & & & & & \\
\hline & \multirow{2}{*}{$\begin{array}{l}\text { A2: 'Social influences' are predictor of } \\
\text { intention to participate }\end{array}$} & A 2.1 & & & & & & \\
\hline & & A 2.2 & & & & & & \\
\hline & \multirow{2}{*}{$\begin{array}{l}\text { A3: 'Facilitating conditions' are } \\
\text { predictor of intention to participate }\end{array}$} & A 3.1 & & & & & & \\
\hline & & A 3.2 & & & & & & \\
\hline & $\begin{array}{l}\text { A4: 'Government supports' are } \\
\text { predictor of intention to participate }\end{array}$ & A 4.1 & & & & & & \\
\hline
\end{tabular}

Figure 3. Average scores of risk perceptions, attitudes, and factors affecting the participation of four hundred respondents to 'microfinance for sea level rise impacts'

Note. (1) R1.1 House and farmland are currently at risks from various impacts of sea level rise e.g. coastal erosion, inundation, and salt water intrusion.

R1.2 Sea level rise impacts result to more health risks e.g. water borne disease.

R1.3 Family financial status has been deteriorated due to the increasing of required costs to adapt to sea level rise impacts.

A1.1 Microfinance can promote cooperatives of social and economic development in a community

A1.2 Having good experiences from using other previous microfinance services

A1.3 Microfinance can be applied as a financial adaptive measure for sea level rise

A2.1 Family members (spouse) influence intention to participate with 'microfinance for sea level rise impacts'.

A2.2 Neighbors influence intention to participate with 'microfinance for sea level rise impacts'.

A3.1 Services quality and related facilitations of microfinance influence intention to participate with 'microfinance for sea level rise impacts'.

A3.2 Membership benefits including terms and conditions of microfinance influence intention to participate with 'microfinance for sea level rise impacts'.

A4.1 Government supports are necessary and influence intention to participate with 'microfinance for sea level rise impacts'. 
Table 4. Ratio of acceptance to 'microfinance for sea level rise impacts', measured from attitudes of respondents

\begin{tabular}{|c|c|c|c|c|c|c|}
\hline \multirow[t]{2}{*}{ Tambons } & \multirow[t]{2}{*}{ Villages } & \multirow[t]{2}{*}{$\begin{array}{c}\text { No. of } \\
\text { respondents }\end{array}$} & \multicolumn{3}{|c|}{$\begin{array}{c}\text { Acceptance ratios }^{(1)} \text { : } \\
\text { Attitudes (A1.1 - A1.3) toward } \\
\text { microfinance } \\
\text { micr }\end{array}$} & \multirow[t]{2}{*}{$\begin{array}{l}\text { Average } \\
\text { acceptance } \\
\text { ratios }\end{array}$} \\
\hline & & & A1.1 & A1.2 & A1.3 & \\
\hline \multirow{2}{*}{$\begin{array}{ll}\text { Phan } & \text { Thai } \\
\text { Norasing } & \end{array}$} & Sahakon & 67 & 0.72 & 0.39 & 0.72 & 0.61 \\
\hline & Sandap & 67 & 0.58 & 0.33 & 0.67 & 0.53 \\
\hline \multirow[t]{2}{*}{ Laem Fapha } & Khun Samut Chin & 65 & 0.65 & 0.46 & 0.71 & 0.60 \\
\hline & Khlong Suan & 67 & 0.49 & 0.29 & 0.42 & 0.40 \\
\hline \multirow[t]{2}{*}{ Khlong Dan } & Si Long & 67 & 0.61 & 0.54 & 0.67 & 0.61 \\
\hline & Khlong Nang Hong & 67 & 0.60 & 0.38 & 0.71 & 0.56 \\
\hline \multicolumn{2}{|c|}{ All villages } & 400 & 0.61 & 0.40 & 0.65 & 0.55 \\
\hline
\end{tabular}

Note. (1) Summation of value respondents assigned to, divided by summation of maximum possible values of attitudes factor

(2) A1.1: Microfinance can promote cooperatives of social and economic development in a community

A1.2: Having good experiences from using other microfinance services

A1.3: Microfinance can be applied as a financial adaptive measure for sea level rise impacts

Table 5. Percentage of respondent's intention to participate to 'microfinance for sea level rise impacts', and their purposes of participation

\begin{tabular}{|c|c|c|c|c|c|}
\hline \multirow{2}{*}{ Tambons } & \multirow[t]{2}{*}{ Villages } & \multirow{2}{*}{$\begin{array}{l}\text { No. } \\
\text { respondents } \\
\text { intended to } \\
\text { participate }\end{array}$} & \multirow{2}{*}{$\begin{array}{l}\text { No. } \\
\text { respondents } \\
\text { not intended } \\
\text { to participate }\end{array}$} & \multirow{2}{*}{$\begin{array}{c}\text { Percentage of } \\
\text { intention to } \\
\text { participate }\end{array}$} & $\begin{array}{l}\text { Percentage of } \\
\text { purposes to } \\
\text { participate }^{(1)}\end{array}$ \\
\hline & & & & & 3 \\
\hline \multirow{2}{*}{$\begin{array}{ll}\text { Phan } & \text { Thai } \\
\text { Norasing } & \end{array}$} & Sahakon & 47 & 20 & $70 \%$ & $33 \% \quad 38 \% \quad 19 \% \quad 10 \%$ \\
\hline & Sandap & 33 & 34 & $49 \%$ & $27 \% \quad 38 \% \quad 27 \% \quad 8 \%$ \\
\hline \multirow[t]{2}{*}{ Laem Fapha } & Khun Samut Chin & 35 & 30 & $54 \%$ & $37 \% \quad 45 \% \quad 13 \% \quad 4 \%$ \\
\hline & Khlong Suan & 17 & 50 & $25 \%$ & $33 \% \quad 39 \% \quad 19 \% \quad 8 \%$ \\
\hline \multirow[t]{2}{*}{ Khlong Dan } & Si Long & 18 & 49 & $27 \%$ & $40 \% \quad 40 \% \quad 10 \% \quad 10 \%$ \\
\hline & Khlong Nang Hong & 32 & 35 & $48 \%$ & $44 \% \quad 33 \% \quad 14 \% \quad 9 \%$ \\
\hline All villages & & 182 & 218 & $46 \%$ & $35 \% \quad 39 \% \quad 18 \% \quad 8 \%$ \\
\hline
\end{tabular}

Note. (1) The purposes of microfinance participation are: 1- for saving; 2- to obtain loan benefits; 3possible attractive interest rates (both saving and loan); 4- no other financial sources to provide financial supports for adaptation

\section{Discussions}

\subsection{Analysis of Acceptance of Microfinance for Sea Level Rise Impacts}

In response to one of hypotheses of this study that microfinance can (cannot) be applied as a financial adaptive measure for the impacts of sea level rise, the acceptance of respondents toward the designed microfinance was examined. It can be assumed that microfinance is applicable for such adaptation purposes if most respondents accept for its benefits. Only attitude factor is examined among other hypothesized factors affecting microfinance participation for analyzing acceptance. This is because attitude leads to behavior toward subject being considered, following the theory of reasoned action (Fishbein \& Ajzen, 1980, cited in French et al., 2005; Ajzen \& Fishbein, 1975). How respondents currently feel about microfinance will indicate their potential acceptance or rejection of 
microfinance if it is applied for adaptation to sea level rise impacts. The other factors affecting microfinance participation, which include risk perceptions, social references, facilitating conditions, and government supports, are not considered for analyzing acceptance as they are the motives for microfinance participation. Accordingly, three predefined items relevant to attitude toward microfinance were asked to respondents. Those items included: 1) attitude that microfinance can promote social cooperatives and economic development in a community; 2) good attitude/ good experiences obtaining from using other previous microfinance services; and 3) attitude that microfinance can be applied for adaptation to sea level rise impacts. Respondents provided their 'disagreement' and 'agreement' by scoring those attitude items.

The study applied methodology of Sahu and Gupta (2007) to calculate the acceptance ratio. Summation of scores that respondents assigned to was divided by summation of maximum possible values of attitude items. The calculation results are shown in Table 4. Interviewing four hundred respondents of all studied villages regarding their attitude toward microfinance, they accepted that microfinance could promote social cooperatives and economic development, including could be applied for adaptation to sea level rise impacts with average acceptance ratios of 0.61 and 0.65 respectively. However, they did not accept that they had good experiences from using other previous microfinance services with average ratio of acceptance at 0.40 . Combining altogether the scores of those three attitudes, the calculated average acceptance ratio was 0.55 . This somehow can be interpreted that applying microfinance as an adaptive measure for sea level rise impacts is acceptable in view of respondents. Nevertheless, the successful implementation including the sustainability of such microfinance yet is depended on other factors than attitudes. Examples of those other factors are service quality and management of microfinance, and community leadership.

Analyzing by individual studied village, the results of respondent's acceptance ratio to measured attitude items are in same direction. Respondents of most villages accepted that microfinance was useful and could be applied for adaptation to sea level rise impacts. However, they complained that they did not obtain good services of some previous microfinances. This raises an interesting point. Despite respondents seldom have good experiences with microfinance's services they yet have had good views on its usefulness. A further investigation on what factors discourage the quality of microfinance services will be benefit for the improvement of existing microfinances including supporting the implementation of any new one. It is a particular note of Khlong Suan village. The average respondent's acceptance ratio of such village toward all measured attitude items is less than half (0.5). Following the interview of respondents who reside in Khlong Suan village, most microfinances have not been successfully implemented in the village due to the poor management of microfinance committee and lacking of leadership in community. This may supports a claim by Zaman (2004) that vision and persistence of the leader of microfinance institution are key factors behind the success of the microfinance.

\subsection{Analysis of Intention to Participate with Microfinance for Sea Level Rise Impacts}

Firstly, it needs to differentiate the analysis of acceptance and the analysis of intention to participate. In this study, respondent's acceptance is examined at preliminary stage (via respondent's state of feeling) for the possibility of applying microfinance for adaptation to sea level rise impacts. Thereafter, respondents' intention to participate with microfinance for sea level rise impacts is measured with an aim for testing market of new product. Individual decision for (non-) participation can be affected by individual factors, social factors, and their prior knowledge (Wang, Dacko \& Gad, 2008) during their evaluation processes.

In order to analyze the intention to participate, the designed hypothetical microfinance for sea level rise impacts including its conditions was presented to respondents. Respondents then were asked about their intention and purposes of participation with such microfinance. The study results are presented in Table 5 . Of the four hundred respondents of all six studied villages, there are one hundred and eighty two respondents (or equivalent to $46 \%$ ) intend to participate with microfinance for sea level rise impacts. The purposes of participation from most to least desires are: a) to obtain loan benefits; b) for saving; c) to obtain attractive interest rates for both loan and saving; and d) due to lack of particular financial sources to support household adaptation, with percentages of 39, 35,18 and 8 respectively. Analyzing by individual studied village, likewise the result of acceptance analysis, the percentage of respondent's intention to participate of Khlong Suan village is lowest at 25\% among other studied villages.

In addition, factors of risk perception to the impacts of sea level rise, attitude toward microfinance, social reference, microfinance facilitating conditions, and government supports were hypothesized that they could affect respondent's intention to participate with microfinance for sea level rise impacts. Those factors were divided into eleven items. Detail of factors and items can be seen in Figure 3. In this study, testing of such hypothesized items was not analyzed by individual village, but altogether for six studied villages. This is due to 
the homogeneity of respondents in the study area as they have same occupations, cultures and live in similar environments. Pearson correlation was used to examine the correlations between intention to participate and those hypothesized affecting items. Considering four hundred respondents of all villages, with significant 2-tails at 0.05 , it was found that respondent's intention to participate was correlated with most of items, except item A1.2 'having good experiences from using other previous microfinance services'. Stepwise regression analysis then was used to determine requisite items that best predicted intention to participate. Stepwise regression is a method for selection numbers of potential independent variables in order to fine-tuning model predicting dependent variable in multivariate statistical analysis (Maitra \& Yan, 2008). It was found that a model containing items A 3.1, A1.3, and R1.1 (ordering from highest correlation) best predict respondent's intention to participate with microfinance for sea level rise impacts. The items A 3.1, A1.3, and R1.1 are respectively 'services quality and facilitations of microfinance', 'microfinance can be applied for adaptation to sea level rise impacts', and 'house and farmland are at risks from impacts of sea level rise'. It is to note that those predictor items A3.1, A1.3, and R1.1 are components of separate hypothesized factors of microfinance facilitating conditions, attitude toward microfinance, and risks perception. Diaphragm of model is presented in the following Figure 4.

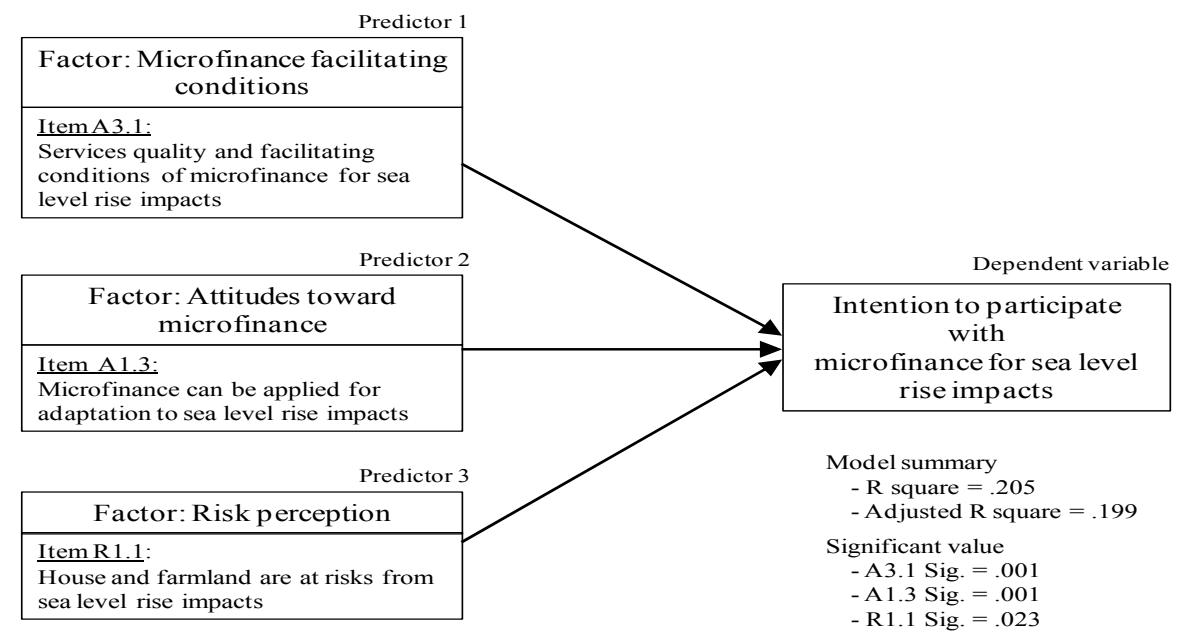

Figure 4. Stepwise regression model for prediction of intention to participate with microfinance for sea level rise impacts

There were queries whether other items that were highly correlated with predictor items might contribute for more fitness of model. Accordingly, those other items were additionally entered into the initial model obtained from stepwise regression analysis. New model then was rerun for regression analysis. It was found that R-square of new model was improved (higher than R-square 0.205 of stepwise model), but the adjusted R-square was reduced (less than adjusted R-square 0.199 of stepwise model). Following Hutcheson (2011) and Gamage et al. (2007), R-square always is increased when new variable added to model. However, adjusted R-square may be reduced indicating that the new variable provide less fitness to the model. This proves that, considering all hypothesized items affecting microfinance participation, combination of items A3.1, A1.3, and R1.1 are the best predictors for the model of intention to participate with microfinance for sea level rise impacts.

One may additionally query about the low value of model adjusted $\mathrm{R}$ square at 0.199 , whether it indicates the sufficiency of model fitness. Pursuant to Simpson et al. (2004), the low value of adjusted R-square may be suggestive that there is little relationship of the independent variables to the dependent variable. In other word, the model fitness is poor. This may be due to the incorrect form of independent variables e.g. outliers, or the errors of independent variables that are not normally distributed. However, in view of Macdonell (2010), human behavior differs from physical system. In predicting human behavior, adjusted R-square between $0.200-0.250$ is normal; reaching 0.400 is considered excellent. Chong, Il-Gyo and Jun (2005) also suggest that considering only good fitness of a model via high value of adjusted R-square may not guarantee good performance of independent variables selection. Therefore, the adjusted $\mathrm{R}$-square value at 0.199 somehow indicates the fair fitness of the model of intention to participate with microfinance for sea level rise impacts.

The study also examined the effect of respondent's demographic factors on the intention to participate. Similarly, Pearson correlation and stepwise regression analysis were applied on data obtained from four hundred respondents of all six studied villages. It was found that demographic factors were not good predictors for 
intention to participate with microfinance for sea level rise impacts.

\section{Conclusions and Recommendations}

This study contributes to the knowledge of adaptation to climate change impacts. Its aim is to study the possible use of microfinance for adaptation to sea level rise impacts at community level. The study examines two hypotheses: 1) microfinance can (cannot) be applied as an adaptive measure to the impacts of sea level rise; 2) whether or not factors of risk perception to the impacts of sea level rise, attitude toward microfinance, social reference, microfinance facilitating conditions, government supports and demographic influence an individual participation to a designed microfinance for sea level rise impacts. With the result of acceptance analysis measured from respondent's attitude toward microfinance, most respondents have accepted for applying microfinance as an adaptive measure to sea level rise impacts. They agree that microfinance can be a self-help financial tool to support their own household adaptations. In addition, they yet have good view with microfinance that it can promote cooperatives of social and economic development in their community, though they have been dissatisfying with services of some other previous microfinance. Regarding factors affecting microfinance participation, of the tested eleven items by statistical analysis tools (Pearson correlation and Stepwise regression), three items influence respondent's intention to participate with microfinance for sea level rise impacts. Those three items are: 1) services quality and facilitating conditions of microfinance; 2) individual attitude that microfinance can be applied for adaptation; and 3) individual perceive of risk that house and farmland are impacted by sea level rise. For the analysis of respondent's demographic factors by similar statistical tools, the results show that there are no significant correlations between those factors and respondent's intention to participate.

From the study results, it can be concluded that microfinance can be applied as a (financial) adaptive measure to the impacts of sea level rise. The likelihood of successful implementation of microfinance to support adaptations will be increased, if those correlated factors affecting participation (facilitating conditions of microfinance, individual attitude toward microfinance, and individual risk perceptions) are properly addressed by implementer. However, how well microfinance can be an effective mean for adaptation is not only depended on the success of initial implementation, but also the maintenance of its performances afterwards. According to Zeller, Lapenu, and Greely (2003), performances of any microfinance are relied on: 1) ability of outreach to client; 2) proper services adjusted to target clients; 3) ability of building up client's social responsibilities; and 4) strengthen social, economic, and political of community. Sustainability, continuity (Churchill, Hirschland \& Painter, 2002) and leadership (Zaman, 2004) also are necessity for performances of microfinance. Those necessitate factors affecting microfinance's performances have to be managed as well to ensure objectives of microfinance are fulfilled.

The study focuses the applicability of microfinance designed for adaptation to sea level rise impacts. The effectiveness of such microfinance in view of self-sufficient of fund (amounts obtained from household's saving to microfinance) to household adaptation cost requirements is not analyzed. This is due to the household adaptation costs to sea level rise impacts need a different study and particular assessment. Without the references of adaptation cost requirements, the effectiveness of microfinance then cannot be examined. Accordingly, an additional study of coastal household adaptation cost requirements for the studied villages is recommended. Given the constant impacts of sea level rise, if financial services of microfinance for sea level rise impacts (including any external financial aids) are sufficient to the adaptation cost requirements, the vulnerability of studied villages will be healed.

\section{Acknowledgement}

The study is partially supported by Research Assistant scholarship from the Faculty of Graduate Studies, Mahidol University, and reviewed the ethic issues by Mahidol University Institutional Review Board

\section{References}

Andrews, M. (2006). Microcredit and agriculture: How to make it work (Mennonite Economic Development Associates). Canada.

Atieno, R. (2001). Formal and informal institutions' lending policies and access to credit by small-scale enterprises in Kenya: An empirical assessment (AERC Research Paper No. 111). Nairobi: African Economic Research Consortium.

Burnetta, W, C., Wattayakorn, G., Taniguchi, M., Dulaiovaa, H., Sojisupornb, P., Rungsupad, S., \& Ishitobi, T. (2007). Groundwater-derived nutrient inputs to the Upper Gulf of Thailand. Continental Shelf Research, 27, 176-190. https://doi.org/10.1016/j.csr.2006.09.006 
Carter, T. R., \& La Rovere, E. L. (2001). Developing and applying scenarios. In J. J. McCarthy, O. F. Canziani, N. A. Leary, D. J. Dokken, \& K. S. White (Eds.), Climate change 2001: Impacts, adaptation, and vulnerability, Contribution of working group II to the third assessment report of the Intergovernmental Panel on Climate Change (pp. 147-181). Cambridge: Cambridge University press.

Chinvanno, S. (2007). Assessment on community vulnerability and adaptation to impact of climate change: Overview of pilot study in Lower Mekong River Region, a Presentation. Bangkok: SEA START Research Center.

Chong, I.-G., \& Jun, C.-H. (2005). Performance of some variable selection methods when multicollinearity is present. Chemometrics and Intelligent Laboratory Systems Journal, 78, 103-112. https://doi.org/10.1016/j.chemolab.2004.12.011

Churchill, C., Hirschland, M., \& Painter, J. (2002). New directions in poverty finance: village banking revisited. USA: The Small Enterprise Education and Promotion (SEEP) Network.

Cutter, S. L. (1996). Vulnerability to environmental hazards. Journal of Progress in Human Geography, 20(4), 529-539. https://doi.org/10.1177/030913259602000407

French, D. P., Sutton, S., Hennings, S. J., Mitchell, J., Wareham, N. J., Griffin, S., Hardeman, W., \& Kinmonth, A. L. (2005). The importance of affective beliefs and attitudes in the theory of planned behavior: Predicting intention to increase physical activity. Journal of Applied Social Psychology, 35(9), 1824-1848. https://doi.org/10.1111/j.1559-1816.2005.tb02197.x

Gamage, J., Linfield, J., Ostaszewski, K., \& Siegel, S. (2007). Statistical methods for health actuaries IBNR estimates: An introduction, p. 31. Illinois: Society of Actuaries.

Haim, R. A., Abidin, F. Z., Zamzuri Noor, M. S., \& Majid, R. (2007). Microfinance service for micro-enterprise: Good practices and performance of selected microfinance institutions in Malaysia. Journal of Yala Rajabhat University, 2(1), 31-45.

Hammill, A., Matthew, R., \& McCarter, E. (2008). Microfinance and climate change adaptation. Institute of Development Studies. IDS Bulletin, 39(4), 113-122. https://doi.org/10.1111/j.1759-5436.2008.tb00484.x

Hocking, R. R. (1976). A biometrics invited paper: The analysis and selection of variables in linear regression. Biometrics, 32, 1-49. https://doi.org/10.2307/2529336

Hoffman, J., Keyes, D., \& Titus, J. (1983). Projecting future sea level rise: Methodology, estimates to the year 2100, and research needs (2nd ed.). (U.S. GPO No. 055-000-00236-3), Washington, D.C.: Government Printing Office.

Hutcheson, G. D. (2011). Ordinary Least-Squares Regression. In L. Moutinho, \& G. D. Hutcheson (Eds.), The SAGE dictionary of quantitative management research (pp. 224-228). London: Sage publications. https://doi.org/10.4135/9781446251119.n67

Jarungrattanapong, R., \& Manasboonphempool, A. (2008). Adaptation strategies for coastal erosion/flooding: A case study of two communities in Bang Khun Thian District. Bangkok: Bangkok Metropolitan Adminitrative Quarterly Review.

Jindal, V., \& Rajulu, K. G. (2010). Microfinance for self help groups. Institute of Secretariat Training \& Management. Government of India.

Klein, R. J. T., \& Nicholls, R. J. (1999). Assessment of coastal vulnerability to climate change. Ambio, 28(2), 182-187.

Kotler, P. (1991). Marketing management: Analysis, planning, implementation, and control (7th ed.). New Jersey: Prentice-hall.

Kouassi-Komlan, E., Faso, B., \& Fonseca, C. (2004). Micro finance for water and sanitation in West Africa, Paper published in 30th WEDC International Conference, pp. 279-282, Vientiane, Lao PDR.

Macdonell, K. (2010) How high, R-squared? Retrieved April 19, 2010, from http://cooldata.wordpress.com/2010/04/19/how-high-r-squared

Maitra, S., \& Yan, J. (2008). Principle component analysis and partial least squares: Two dimension reduction techniques for regression. Discussion paper, p. 79, Casualty Actuarial Society.

Malik, A., Qin, X., \& Smith, S. C. (2010). Autonomous adaptation to climate change: A literature review, Institute for International Economic Policy (IIEP), Working Paper 2010-24, P. 5, Washington: George 
Washington University.

Mclean, R. F., \& Tsyban, A. (2001). Coastal Zones and Marine Ecosystems. In McCarthy, J. J., Canziani, O. F., Leary, N. A., Dokken, D. J., \& White, K. S. (Eds.), Climate Change 2001: Impacts, Adaptation, and Vulnerability, Contribution of Working Group II to the Third Assessment Report of the Intergovernmental Panel on Climate Change (pp. 345-372). Cambridge: Cambridge University Press.

Meehl, G. A. et al. (2007). Global climate projections. In S. Solomon, D. Qin, M. Manning, Z. Chen, M. Marquis, K. B. Averyt, ... H. L. Miller (Eds.), Climate Change 2007: The Physical Science Basis, Contribution of Working Group I to the Fourth Assessment Report of the Intergovernmental Panel on Climate Change (pp. 747-846). Cambridge: Cambridge University Press.

Messner, F., \& Meyer, V. (2005). Flood damage, vulnerability and risk perception challenges for flood damage research. Discussion paper 13/2005, Leipzig: Department of Economics, UFZ-Umweltforschungszentrum Leipzig-Halle.

Nicholls, R. J. (2003). Improving information for policy makers: Case study on sea-level rise impacts. OECD workshop on the benefits of climate policy, Organisation for Economic Co-operation and Development. (ENV/EPOC/GSP(2003)9/FINAL).

Nicholls, R. J. (2007). Adaptation Options for Coastal Areas and Infrastructure: An Analysis for 2030. Bonn: United Nations Framework Convention on Climate Change.

Niemirowski, P., Baldwin, S., \& Wearing, A. J. (2003). Tax related behaviors, beliefs, attitudes and values and taxpayer compliance in Australia. Journal of Australian taxation, 6(1), 132-165.

Pettengell, C. (2010). Climate change adaptation: Enabling people living in poverty to adapt. Oxfam research report, Oxfam International.

Sahu, G. P., \& Gupta, M. P. (2007). User's acceptance of E-Government: A study of Indian Central Excise. International Journal of Electronic Government Research, 3(3), 1-21. https://doi.org/10.4018/jegr.2007070101

Sathaye, J. A., \& Christensen, J. (1998). Introduction. In Mitigation and adaptation costs assessment: Concepts, methods and appropriate use (pp. 9-15). Denmark: UNEP Collaborating Center on Energy and Environment.

Schneider, S., \& Sarukhan, J. (2001). Overview of Impacts, Adaptation, and Vulnerability to Climate Change. In J. J. McCarthy, O. F. Canziani, N. A. Leary, D. J. Dokken, \& K. S. White (Eds.), Climate change 2001: Impacts, adaptation, and vulnerability, Contribution of working group II to the third assessment report of the Intergovernmental Panel on Climate Change (pp. 77-100). Cambridge:, Cambridge University press.

Simpson, P., Hamer, R., Jo, C. H., Huang, B. E., Goel, R., Siegel, E., Dennis, R., \& Bogle, M. L. (2004) Assessing model fit and finding a fit model, Proceedings, SAS Users Group International Meeting, May 9-12, 2004, Cary, North Carolina, Paper No. 214-29.

Smit, B., \& Pilifosova, O. (2001). Adaptation to climate change in the context of sustainable development and equity. In McCarthy, J. J., Canziani, O. F., Leary, N. A., Dokken, D. J., \& White, K. S. (Eds.), Climate Change 2001: Impacts, Adaptation, and Vulnerability, Contribution of Working Group II to the Third Assessment Report of the Intergovernmental Panel on Climate Change (pp. 147-181). Cambridge: Cambridge University Press.

Smith, J. B., \& Tirpak, D. A. (1990). The potential effects of global climate change on the United States. Washington D.C.: Hemisphere Publishing Corporation.

Thorne, S., Kantor, B., \& Hassain, I. (2007). Community based technology solutions adapting to climate change. Cape Town: South African Climate Action Network (SACAN).

Togba, L. (2009). Microfinance, social capital and household access to credit: Evidence from Cote d'Ivorie, pp. 20-22. Cote d'Ivoire: University of Cocody - Abidjan.

Umitsu, M. (2000). Geo-environment and effect of sea level rise in the Chao Phraya Delta. In The International Conference on the Chao Phraya Delta: Historical Development, Dynamics and Challenges of Thailand's Rice Bowl (pp. 153-158, 12-15 December 2000). Bangkok: Kasetsart University.

United Nations. (2005). Planning and executive survey (Chapter 2). In Designing household survey samples: Practical guidelines, United Nations Publication No. ST/ESA/STAT/SER.F/98, pp. 9-26, New York: Department of Economic and Social Affairs. 
Wang, Q., Dacko, S., \& Gad, M. (2008). Factors influencing consumers' evaluation and adoption intention of really-new products or services: Prior knowledge, innovativeness and timing of product evaluation. Advances in consumer research, 35, 416-422.

Wigley, T. M. L., \& Raper, S. C. B. (1992). Implications for Climate and Sea Level of Revised IPCC Emission Scenarios. Nature, 357, 293-300. https://doi.org/10.1038/357293a0

Zaman, H. (2004). Microfinance in Bangladesh: Growth, achievements, and lessons, p. 7, Scaling up poverty reduction: A global learning process and conference, Shanghai, May 25-27, 2004.

Zeller, M., Lapenu, C., \& Greeley, M. (2003). Measuring social performance of micro-finance institutions: A proposal Social Performance Indicators Initiative (SPI). The Final Report submitted to Argidius Foundation and Consultative Group to Assist the Poorest (CGAP). Retrieved August 5, 2010, from http://www.cerise-microfinance.org/publication/pdf/impact/SPI-summary.pdf

\section{Copyrights}

Copyright for this article is retained by the author(s), with first publication rights granted to the journal.

This is an open-access article distributed under the terms and conditions of the Creative Commons Attribution license (http://creativecommons.org/licenses/by/4.0/). 